\title{
СПОСОБИ ГОТУВАННЯ, СПОСОБИ ВЧИНЕННЯ ЗЛОВЖИВАННЯ ПОВНОВАЖЕННЯМИ ОСОБАМИ, ЯКІ НАДАЮТЬ ПУБЛІЧНІ ПОСЛУГИ ТА СПОСОБИ МАСКУВАННЯ ЗЛОЧИННИХ ДІЙ
}

Косаняк С. С.

у науковій статmі досліджено такі важливі складові криміналістичної характеристики зловживання повноваженнями особами, які надають публічні послуги, як способи готування цього злочину, способи його вчинення та спо соби маскування злочинних дій. Доведено, що аналізований злочин з огляду на спосіб $\epsilon$ повноструктурним, а для спеціальних суб'єктів, які перелічені у частині $1 \mathrm{cmammi} 365^{2} \mathrm{KK}$ України та надають публічні послуги, найтиповішим способом зловживання повноваженнями $\epsilon$ вимагання та отримання неправомірної вигоди.

Ключові слова: кримінальне провадження, криміналістична характеристика, способи готування, способи вчинення, способи приховування (маскування).

В научной статье исследованы такие важные составляющие криминалистической характеристики злоупотребления полномочиями лицами, предоставляющими публичные услуги, как способы приготовления этого преступления, способы его совершения и способы маскировки преступных действий. Доказано, что рассматриваемое преступление, учитывая способ, является полноструктурным, а для специальных субъектов, перечисленных в части $1 \mathrm{cma}$ тьи $365^{2}$ УК Украины и которые предоставляют публичные услуги, типичным способом злоупотребления полномочиями является вымогательство и получение неправомерной выгоды.

Ключевые слова: уголовное производство, криминалистическая характеристика, способы приготовления, способы совершения, способы сокрытия (маскировки).

In the scientific article, the following important elements of the forensic character of abuse of authority by persons providing public services are investigated, as methods of preparation for this crime, methods of its commission and methods of masking criminal acts. It is proved that the analyzed methodological crime is fully structured, and for the special subjects listed in paragraph 1 of Article $365^{2}$ of the Criminal Code of Ukraine and providing public services the most typical way of abuse of authority is the extortion and receipt of unlawful benefits.

It has been established that ways of abuse of authority by persons providing public services in practically all investigated cases are full-structured, that is, existing preparatory actions, direct execution in a certain way, and different ways of concealing criminal consequences.

Typical methods of preparation for such a crime are the development of the plan by the organizer, the arrangement of agreements, the selection of participants, the division of duties between them, falsification of documents, falsified information which will facilitate the unhindered implementation of the plan of committing a crime, etc. All of these actions are ultimately aimed at obtaining unlawful benefits. It has been established that it is extremely difficult to prove the way of preparation in the process of pre-trial investigation and court proceedings, since only legitimate, timely and successful conduct of secret investigative (search) actions, conducting of examinations, examination of given testimonies, etc. can provide convincing evidence of such activity.

The ways of committing abuse of authority by persons providing public services are diverse, they belong to the elements of the objective aspect of this crime, this is an optional feature and directly depends on the powers that are assigned to the special actors listed in Article $365^{2}$ (1) of the Criminal Code of Ukraine. At the same time, for all these special actors providing public services, the most common way of abusing authority is to extort and obtain unlawful benefits.

Masking is provided by a set of measures to conceal the illegal nature of the acts committed: the perpetrators skillfully operate gaps in the current legislation; refer to an inadequate legal basis for their activities, interpreting it as proper; lobbying for legislative changes that allow perceiving the criminal results of abuse of authority by those who provide public services as legitimate achievements that are implemented within the current legal framework; material traces are destroyed (with the falsification of documents, too, can act as a way of disguise).

Key words: criminal proceedings, forensic characteristics, methods of preparation, methods of committing, methods of concealment (disguise).

Постановка проблеми та їі актуальність. Зловживання повноваженнями особами, які надають публічні послуги належить до корупційних злочинів, які розслідувати та доказувати вину чи невинуватість певної особи вкрай важко. В першу чергу це пов'язане із не зовсім вдалою конструкцією статті $365^{2}$ КК України, а глобальною проблемою $\epsilon$ відсутність придатної для застосування методики розслідування цього злочину. Дана публікація покликана пролити світло на таку складову криміналістичної характеристики як спосіб зловживання повноваженнями особами, які надають публічні послуги, що у сукупності з іншими елементами криміналістичної характеристики створить в подальшому можливість напрацювання методики розслідування. Вказане у своїй сукупності визначає актуальність задекларованої проблематики.

Аналіз останніх досліджень і публікацій. Фахівцями із суміжних спеціальностей захищено ряд дисертаційних досліджень, які стосуються кримінологічної характеристики корупційних злочинів, їх складу, проблем кваліфікації, які ми використовуємо при написанні даної статті із належними посиланнями. За спеціальністю 12.00.09. у 2018 році захищено дисертацію 0.О. Харловим на тему: «Розслідування злочинів у сфері професійної діяльності, пов'язаної з наданням публічних послуг», яка $\epsilon$ вдалим кроком до вирішення певної кількості із означених вище проблем. Однак спосіб зловживання повноваженнями особами, які надають

Косаняк С. С., 2019 
публічні послуги не знайшов свого повноструктурного висвітлення у згаданій роботі.

Метою статті $\epsilon$ визначити способи готування, способи вчинення зловживання повноваженнями особами, які надають публічні послуги та способи маскування злочинних дій.

Виклад основного матеріалу. Оськільки нами вже встановлено, що зловживання повноваженнями особами, які надають публічні послуги належить до корупційних злочинів, то способи такого виду злочинів здебільшого $\epsilon$ повноструктурними, тобто складаються з операцій із підготовки, виконання дій, безпосередньо спрямованих на досягнення злочинних цілей, i щодо приховання вчиненого діяння. У способах їх здійснення відображаються властивості особистості кількох учасників. Ступінь такого відображення може бути різним у залежності від ролі кожного суб'єкта, його активності, кількості учасників і т. п. [1]. При цьому побутує й інша думка, начебто підготовка до корупційних злочинів $\epsilon$ необов' язковою [2, с. 8]. На наше переконання, що також підкріплене результатами проведеного нами опитування, корупційні злочини, зокрема зловживання повноваженнями особами, які надають публічні послуги, ретельно готуються: здійснюється підбір співучасників, заздалегідь продумуються способи їх реалізації та приховування злочинних наслідків.

Особливості способів таких злочинів полягають у тому, що вони застосовуються не як одиничні дії, а найчастіше у вигляді продуманої системи злочинної діяльності, яка здійснюється протягом тривалого періоду. Спосіб приховування цих злочинів нерідко є складовим елементом злочинної діяльності, здійснюваної відповідно до єдиного задуму, тобто спосіб приховування завчасно передбачається. Дії осіб, спрямовані на вчинення і приховування означених злочинів, можуть не збігатися за суб'єктом у випадку, якщо приховування здійснюється не виконавцем, а іншими заінтересованими особами. Дії по вчиненню і приховуванню зловживання повноваженнями особами, які надають публічні послуги можуть не збігатися й за задумом, якщо необхідність маскування виникла у зв'язку з непередбачуваними обставинами або зміною обстановки. Або ж навпаки, приховування зловживання повноваженнями особами, які надають публічні послуги, яке проявилося у пасивних діях, може здійснюватися після настання наслідків злочинної діяльності [3, с. 505-506].

Розробляється спільний план дій корупціонерів, підготовки і прийняття відповідних актів, складання інших документів для створення умов, що сприятимуть вчиненню злочину. Загальним способом вчинення всіх корупційних злочинів $є$ зловживання наданими повноваженнями, у нашому випадку своїми повноваженнями зловживають особи, які надають публічні послуги. До групових способів вчинення таких злочинів віднесено: незаконні дії з майном, що перебуває у віданні або на яке розповсюджується вплив суб'єкта корупції, отримання незаконної вигоди суб'єктом корупції чи близькими особами, не пов'язане з розкраданням майна, службове підроблення, інші види зловживання владою та службовим становищем. На підставі аналізу емпіричних джерел до головних способів приховування злочинів, пов'язаних з корупцією, віднесено фальсифікацію обліку й звітності; внесення змін до документів; заміну або виготовлення фіктивних документів; знищення документів; штатні переміщення; знищення матеріальних слідів злочину; підписання актів здачі-прийняття замовлених послуг без їх існування. Крім того, встановлено, що такий корупційний злочин як службове підроблення $є$ самим способом приховування інших злочинів у сфері службової діяльності [2, с. 8-9], зокрема і зловживання повноваженнями особами, які надають публічні послуги.

При цьому не всі вище перераховані групові способи вчинення та приховування корупційних злочинів однаковою мірою належать й до зловживання повноваженнями особами, які надають публічні послуги. Адже цей злочин, перш за все, відрізняється від інших корупційних та «службових» злочинів тим, що вчиняється визначеними у частині 1 статті $365^{2}$ КК України спеціальними суб'єктами. Серед оптимальних критеріїв віднесення осіб за професійною ознакою до такого переліку варто вважати: діяння вчинене при виконанні повноважень, пов'язаних із наданням публічних послуг; не $\epsilon$ державним службовцем, посадовою особою місцевого самоврядування, але здійснює професійну діяльність, пов'язану з наданням публічних послуг; $\epsilon$ працівником державної, комунальної, приватної установи, діяльність якої пов'язана з наданням публічних послуг [4, с. 44].

Спосіб підготовки зловживання повноваженнями особами, які надають публічні послуги можна прослідкувати також і з матеріалів емпірики. Так, проведеним нами вивченням вироків встановлено, що такий спосіб підготовки доводити у процесі досудового розслідування та судового розгляду вкрай не легко, адже лише законне, вчасне і вдале провадження негласних слідчих (розшукових) дій, проведення експертиз, перевірка наданих показань тощо можуть забезпечити переконливі докази такої діяльності. Так відбулося у справі №201/8471/14-к [5], у цьому випадку в процесі досудового розслідування та судового розгляду доведено тривалу підготовку та епізодність вчинення зловживання повноваженнями особою, яка надавала публічні послуги. Адже очевидним $\epsilon$ факт, що після вступу у злочинну змову арбітражний керуючий ОСОБА_2, діючи з умислом, направленим на отримання неправомірної вигоди для товариства з обмеженою відповідальністю «СОЛЯРИС» у вигляді набуття права власності на об'єкти нерухомості, вчинила цілу низку підготовчих протиправних дій, які переслідували мету - отримання неправомірної вигоди для товариства з обмеженою відповідальністю «СОЛЯРИС». Загальними способами готування у цьому випадку варто вважати розроблення плану, налагодження домовленостей, розподіл обов'язків, підробку документів тощо.

При цьому в процесі досудового розслідування та судового розгляду не вдалося доказати такий елемент спеціальної злочинної мети, як отримання неправомірної вигоди для себе.

Також схожі способи готування до зловживання повноваженнями особами, які надають публічні послуги прослідковуються по справі 301/2625/14-к [6]. Варто відзначити, що способи готування, у порівнянні із першим розглянутим нами випадком, полягали ще й у розподілі ролей та обмані.

Вважаємо, що вище описані способи готування до вчинення зловживання повноваженнями особами, які надають публічні послуги є досить загальними, а тому можуть бути притаманні переважній більшості спеціальних суб'єктів, які закріплені у частині 1 статті $365^{2}$ КК України. 
Додатково підкреслимо, що у юридичній літературі серед загальних способів готування до вчинення корупційного злочину, зокрема і такого, як зловживання повноваженнями особами, які надають публічні послуги, виділено й деякі схожі, а також інші способи. Зокрема, деякі особи, прагнучи отримати дозвіл на ведення будьякої діяльності, вирішують, що краще всього це зробити за допомогою підкупу. Ті, у кого відсутні корупційні зв'язки, намагаються їх налагодити. Встановивши їх, вони узгоджують свої дії і послідовність їх здійснення з кожним з учасників запланованого злочину.

Іноді корупційні зв'язки встановлюються без узгодження майбутніх дій посадових осіб чи осіб, які надають публічні послуги. У деяких ситуаціях здійснюється завчасний підкуп за допомогою передачі дорогих подарунків і надання безкоштовних послуг близьким або самим майбутнім фігурантам по кримінальних провадженнях без попередньої домовленості про виконання ними яких-небудь дій. При виникненні необхідності у сприянні чиновника чи особи, яка надає публічні послуги до них звертаються за допомогою, а в разі відмови шантажують.

Під час досягнення домовленості співучасниками розробляється загальний план дій, визначаються розміри та строки отримання незаконної винагороди, вирішуються питання про необхідність залучення до злочину інших осіб і т. д.

У деяких випадках на стадії підготовки корупційного злочину готуються і приймаються нормативні акти, складаються інші документи в цілях створення умов, сприятливих для здійснення запланованого діяння [1].

Вивченням дисертації О.О. Харлова нами встановлено, що хоча ним не приділялася достатня увага способам готування до розглядуваного злочину, однак способи вчинення злочинів, передбачених статтями $365^{2}$ та $368^{4}$ КК України ним досліджено на гідному рівні. Так, цим дослідником відзначено, що основним способом їх вчинення $\epsilon$ прийняття рішення всупереч нормативно закріплених повноважень уповноваженою особою. У той же час, спосіб вчинення злочинів у сфері професійної діяльності, пов'язаної з наданням публічних послуг характеризується своїми власними властивостями, притаманними лише даному виду злочинів [4, с. 45].

Спосіб вчинення будь-якого злочину належить до елементів об'єктивної сторони цього злочину, це факультативна ознака, не винятком $€$ і зловживання повноваженнями особами, які надають публічні послуги.

Об'єктивна сторона конкретного складу злочину може бути визначена по-різному: по-перше, коли у диспозиції статті вказується лише суспільно небезпечне діяння (дія або бездіяльність); по-друге, коли у ній передбачено не лише діяння, а й суспільно небезпечні наслідки. У першому випадку склади злочинів належать до формальних або усічених, а в другому - до матеріальних. Склад злочину, передбачений у статті $365^{2}$ КК України, - матеріальний. Відповідно ознаками об'єктивної сторони зловживання повноваженнями особами, які надають публічні послуги $\epsilon$ такі: 1) діяння - зловживання своїми повноваженнями; 2) наслідки - істотна шкода охоронюваним законом правам або інтересам окремих громадян, державним чи громадським інтересам або інтересам юридичних осіб; 3) причинний зв'язок між діянням та наслідками [7, с. 81-82].
Якщо зловживання владою або службовим становищем як спосіб вчинення низки злочинів містить і наукові тлумачення $[8,9]$, і висновки, які слідують із судової практики [10], і є емпіричні дослідження, які підтверджують, що воно може бути вчинено як шляхом дії, так і шляхом бездіяльності [7, с. 83] (при цьому відсоток неактивних дій (бездіяльності) $€$ мізерним, і коливається від 3 до 5 [8, с. 7]), то із зловживанням повноваженнями, як способом вчинення злочинів ситуація більш проблематична. Такий спосіб вчинення притаманний двом нормам КК України, зокрема, статтям $364^{1}$ та $365^{2}$ КК. Крім того, сама диспозиція частин перших означених статей КК України містить вказівку на таке зловживання своїми повноваженнями суб'єктом, при цьому розкриваючи, що таке зловживання владою або службовим становищем, законодавець не визначає, що таке зловживання повноваженнями [7, с. 83].

$€$ наукова думка, що законодавець такий стан речей створив виправдано, оскільки надання публічних послуг здійснюється з метою задоволення певного соціального інтересу чи потреби, формулюванням яких наштовхується на труднощі, але при цьому вимагає диференціації по способу вчинення [9, с. 79].

Інші дослідники $є$ більш прагматичними та вважають, що зловживання повноваженнями - це вчинене всупереч інтересам фізичних та юридичних осіб будь-яке використання особою наданих їй повноважень у зв'язку зі здійсненням професійної діяльності з надання публічних послуг. Зловживанням визнається не будьяке діяння, а лише таке, що стосується: а) професійної діяльності, пов'язаної з наданням публічних послуг; б) наданих особі повноважень. При вчиненні цього зло-

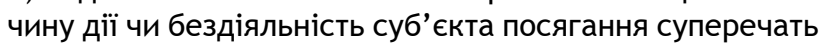
як загальним принципам, меті та завданням функціонування відповідної установи (аудиторської фірми чи компанії, нотаріальної контори, трудового арбітражу), так і загальній меті та змісту надання публічних послуг, для забезпечення якого така особа мала відповідні права та була наділена відповідними повноваженнями. Компетенція особи, котра здійснює професійну діяльність, пов'язану з наданням публічних послуг, визначається, зокрема, законами, постановами, наказами, положеннями, інструкціями, актами індивідуальної дії та договорами (щодо незалежного посередника). Власне зловживання може виявлятися у вчиненні суб'єктом певних протиправних дій, наданні невідповідних чи не у повному обсязі послуг, встановленні певних заборон, створенні перепон для реалізації громадянами передбачених законодавством прав і свобод, що в цілому сприяє отриманню неправомірної вигоди [11].

М.В. Рябенко цілком виправдано вважає, що базовим словосполученням, яке й визначає зміст поняття «зловживання повноваженнями» $€$ власне використання повноважень. Цей дослідник, провівши глибокий аналіз різних наукових, правових точок зору підкреслює, що щодо розуміння змісту поняття «зловживання повноваженнями» у теорії кримінального права склалося декілька підходів. Перший підхід - вузький, він базується на тому, що це вчинення суспільно небезпечного діяння виключно в межах повноважень особи. Другий підхід - широкий, відповідно до нього використання повноважень включає вчинення таких діянь: 1) у межах службових повноважень особи; 2) безпосередньо не пов'язаних з обов'язками особи по службі, а які ґрун- 
туються на їі авторитеті, зв'язках; 3) виходять за межі іï службових повноважень. Тобто, згідно з таким широким трактуванням зловживання повноваженнями охоплює й їх перевищення, коли особа, вчиняючи діяння, виходить за їх межі. М.В. Рябенко також переконує нас у тому, що таке ж широке розуміння поняття «зловживання» міститься і в Конвенції ООН проти корупції. Згідно зі статтею 19 цієї Конвенції умисне зловживання службовими повноваженнями або службовим становищем визнається здійснення будь-якої дії чи утримання від здійснення дій, що $є$ порушенням законодавства, державною посадовою особою під час виконання своїх функцій з метою одержання будь-якої неправомірної вигоди для самої себе чи іншої фізичної або юридичної особи. Тобто, зловживання владою або службовим становищем (повноваженнями) охоплює і перевищення [7, с. 84-85].

Основний елемент способу вчинення корупційного злочину складається з двох частин - вчинення дії (або бездіяльності) та отримання незаконної матеріальної вигоди для себе, близьких, інших осіб або задоволення інших у тому числі й особистих інтересів [1].

Роблячи висновки про способи вчинення злочинів, передбачених статтями $364^{1}$ та $365^{2}$ КК України, О.О. Харлов виходив із повноважень, якими наділені спеціальні суб'єкти, які перелічені у частині 1 статті $365^{2} \mathrm{KK}$ України. На наше переконання, такий підхід $є$ цілком логічним та виправданим. Так, цим дослідником констатовано, для прикладу, що враховуючи повноваження, якими наділені аудитори, а також думки практичних працівників, найчастіші способи вчинення злочинів даними особами можуть бути такими: використання під час аудиторської перевірки документи, які містять ознаки підробки (25,8 \% прокурорів та 23,9 \% слідчих); зміна інформації в облікових документах під час здійснення аудиторської перевірки (12,4 \% прокурорів та 14,3 \% слідчих); не внесення інформації в облікових документах під час здійснення аудиторської перевірки (8,6 \% прокурорів та 7,6 \% слідчих); вказівка в облікових документах неіснуючої інформації про проведення операцій підприємством, установою, організацією (12,5 \% прокурорів та 17,3 \% слідчих); навмисний пропуск інформації про певні операції проведені підприємством, установою, організацією $(15,1$ \% прокурорів та $13,9 \%$ слідчих).

Hотаріуси найчастіше вчиняють розглядуваний нами злочин такими способами, як підробка витягу 3 державного реєстру прав власності на майно (такої думки 21,8 \% опитаних прокурорів та 22,4 \% опитаних слідчих органів досудового розслідування); внесення недостовірної інформації до офіційної бази даних (34,1 \% прокурорів та 34,9 \% слідчих) та використання документів, під час проведення нотаріальних операцій, з явними ознаками підробки (15,1% прокурорів та $16,1 \%$ слідчих).

Оцінювачі віддають перевагу підробці результатів оцінки (15,3 \% прокурорів та 21,9 \% слідчих); використанню під час проведення оцінки недостовірних математичних даних (25,3 \% прокурорів та 31,4 \% слідчих) та внесенню до інформації про результати оцінки недостовірної інформації (18,2 \% прокурорів та 16,1 \% слідчих). Також ними завищується або занижується оціночна вартість об'єкта оцінки, всупереч нормативно визначених вимог (17,4 \% прокурорів та 18,3 \% слідчих).
Судові експерти зловживають своїми повноваженнями в спосіб підробки результатів експертного дослідження (7,2 \% прокурорів та 4,4 \% слідчих); використання під час проведення дослідження зразків, що не відповідають правильній процедурі їх вилучення (6,2 \% прокурорів та 8,8 \% слідчих); порушення під час визначених норм зберігання зразків для експертного дослідження (8,9 \% прокурорів та 8,2 \% слідчих) чи навмисного пошкодження експертного зразка, необхідного для подальшого дослідження (10,1 \% прокурорів та 14,7 \% слідчих).

Арбітражними керуючими найчастіше допускається підробка документів під час ліквідації суб'єкта-банкрота (21,1 \% прокурорів та 22,2 \% слідчих); внесення недостовірної інформації до установчих даних суб'єкта-банкрота (8,5\% прокурорів та 4,3 \% слідчих); видача недостовірної інформації про майно та активи суб'єкта-банкрота (11,5 \% прокурорів та 7,2 \% слідчих); завищення або заниження активів суб'єкта-банкрота (23,1 \% прокурорів та 20,7 \% слідчих), а також проведення незаконних фінансових операцій (17,9 \% прокурорів та $18,6 \%$ слідчих).

Незалежні посередники, члени трудового арбітражу, а також третейські судді (під час виконання цих функцій) для ефективного зловживання своїми повноваженнями застосовують такі способи, як прийняття завідомо неправомірного рішення під час вирішення трудових спорів (22,5 \% прокурорів та 22,2 \% слідчих); підробка документів, які $\epsilon$ підставою прийняття рішення $(18,1 \%$ прокурорів та 22,7 \% слідчих); підробка рішення щодо трудового спору (14,6 \% прокурорів та $18,9 \%$ слідчих).

Державні та приватні виконавці при своїх зловживаннях допускають підробку офіційних документів у виконавчій справі щодо майна, активів, які потребують арешту, вилучені (13,2 \% прокурорів та 15,5 \% слідчих) [4, с. 46-52].

Для всіх означених спеціальних суб'єктів, які надають публічні послуги найтиповішим способом зловживання повноваженнями $\epsilon$ вимагання та отримання неправомірної вигоди (такої думки 39,5 \% опитаних прокурорів та слідчих органів досудового розслідування) $[4$, c. 52$]$.

Приблизно така ж статистика і динаміка щодо способів вчинення зловживання повноваженнями особами, які надають публічні послуги слідує також із дослідженої нами емпірики, зокрема оприлюднених вироків [5; 6; 12-15].

Для приховування злочинів розглядуваної категорії насамперед маскується протиправний характер виконуваних дій. У цих цілях використовуються прогалини в нормах права, приймаються рішення про внесення до них змін, щоб створити сприятливі можливості для корупційних діянь; виконуваним протиправним діям надається вигляд законних шляхом посилання на незастосовні в даному випадку норми; проводяться формальні обговорення, виконуються інші процедури, а також складаються і використовуються фальсифіковані документи, що містять фактичні підстави для вчинення дій.

Деякі дії з приховання відбуваються за межами способу вчинення зловживання повноваженнями особами, які надають публічні послуги. Вже після початку перевірок законності виконаних дій раніше складені документи можуть фальсифікуватися або знищуватися. 
У практиці зустрічаються і випадки встановлення корупційних зв'язків з особами, які здійснюють відомчі або позавідомчі перевірки, а також досудове провадження за фактами зловживань [1].

Також серед способів приховування зловживання повноваженнями особами, які надають публічні послуги не останнє місце посідає знищення матеріальних слідів злочину [3, с. 506].

Висновки. Отже, нами встановлено, що способи зловживання повноваженнями особами, які надають публічні послуги практично у всіх досліджених випадках $\epsilon$ повноструктурними, тобто наявні підготовчі дії, безпосереднє вчинення у певний спосіб та різні способи приховування злочинних наслідків.

Для цього злочину характерними $\epsilon$ такі способи готування, як розробка плану організатором, налагодження домовленостей, підбір учасників, розподіл між ними обов'язків, підробка документів, фальсифіковані відомості з яких сприятимуть безперешкодній реалізації плану вчинення злочину тощо. Всі означені дії в кінцевому результаті направлені на отримання неправомірної вигоди. Встановлено, що спосіб підготовки доводити у процесі досудового розслідування та судового розгляду вкрай не легко, адже лише законне, вчасне і вдале провадження негласних слідчих (розшукових) дій, проведення експертиз, перевірка наданих показань тощо можуть забезпечити переконливі докази такої діяльності.

Способи вчинення зловживання повноваженнями особами, які надають публічні послуги $є$ різноманітними, вони належать до елементів об'єктивної сторони цього злочину, це факультативна ознака та напряму залежать від повноважень, якими наділені спеціальні суб'єкти, які перелічені у частині 1 статті $365^{2}$ КК України. При цьому для всіх цих спеціальних суб'єктів, які надають публічні послуги найтиповішим способом зловживання повноваженнями $€$ вимагання та отримання неправомірної вигоди.

Маскування забезпечується комплексом заходів по приховуванню протиправного характеру виконуваних дій: злочинці вміло оперують прогалинами чинного законодавства; посилаються на неналежну правову основу своєї діяльності, трактуючи ії як належну; лобіюють законодавчі зміни, що дозволяють сприймати злочинні результати зловживання повноваженнями особами, які надають публічні послуги як законні здобутки, що реалізовані в рамках чинного правового поля; знищуються матеріальні сліди (при цьому підробка документів теж може виступати способом маскування).

\section{Література}

1. Конспект лекцій. Право. Криміналістика. Лекція 35: Розслідування корупційних злочинів. Криміналістична характеристика корупційних злочинів. URL: https:// studme.com.ua/140405097536/pravo/rassledovanie_ korruptsionnyh_prestupleniy.htm.
2. Кимлик Н.В. Особливості розслідування злочинів, пов'язаних із корупцією: автореф. дис. ... канд. юрид. наук : спец. 12.00.09. Ірпінь: Нац. ун-т держ. податкової служби України, 2013. 18 с.

3. Криміналістика : підручник для студ. юрид. спец. вищ. закл. освіти. / кол. авторів: Глібко В.М., Дудніков А.Л., Журавель В.А. та ін. / За ред. В.Ю. Шепітька. Київ : Видавничий дім «Ін Юре», 2001. 684 с.

4. Харлов 0.0. Розслідування злочинів у сфері професійної діяльності, пов'язаної з наданням публічних послуг : дис... канд. юрид. наук : спец. 12.00.09. Київ : ПВНЗ «єропейський університет», 2018. 221 с. URL: https:// e-u.in.ua/userfiles/files/118/43/disertaciya-harlova-o-o-2.pdf.

5. Рішення у справі № 201/8471/14-к (кримінальні справи (до 01.01.2019)). URL: http://www.reyestr.court. gov.ua/Review/40664063.

6. Рішення у справі № 301/2625/14-к (кримінальні справи (до 01.01.2019)). URL:http://www.reyestr.court.gov.ua/ Review/42602440.

7. Рябенко М.В. Кримінально-правова охорона професійної діяльності, пов'язаної з наданням публічних послуг : дис. ... канд. юрид. наук : спец. 12.00.08. Київ : Ген. прокуратура України, Нац. акад. прокуратури України, 2016. 267 c. URL: https://ap.gp.gov.ua/userfiles/file/ Academia2016/Ryabenko_diser.pdf.

8. Хашев В.Г. Кримінальна відповідальність за зловживання владою або службовим становищем : автореф. дис.... канд.. юрид. наук : спец. 12.00.08. Київ, 2007. 24 с.

9. Киричко В.М. Кримінальна відповідальність за корупцію : науково-практичний коментар. Харків: Право, 2013. $424 \mathrm{c}$

10. Правові висновки Верховного Суду України, викладені у Постанові № 5-109кс15. Збірник правових висновків Верховного Суду України. URL: https://ksa.court.gov.ua/ sud2190/science_work/rozdil2/zbirnikverhsud.

11. Савченко А.В. Корупційні злочини (кримінально-правова характеристика) URL: https://pidruchniki.com/ 88557 /pravo/zlovzhivannya_povnovazhennyami_osobami_ nadayut_publichni_poslugi_365-2_ukrayini.

12. Рішення у справі № 359/5521/16-к (кримінальні справи (до 01.01.2019)). Результат оскарження: 08.06.2017 Апеляційний суд Київської області: скасовано вирок повністю з поверненням справи на новий судовий розгляд у суд першої інстанції URL: http://www.reyestr.court.gov.ua/ Review/64410640.

13. Рішення у справі № 759/8499/16-к (кримінальні справи (до 01.01.2019)). URL: http: / /www.reyestr.court.gov.ua/ Review/59832925.

14. Рішення у справі № 552/2170/15-к (кримінальні справи (до 01.01.2019)). URL: http://www.reyestr.court.gov.ua/ Review/54482394.

15. Рішення у справі № 552/2170/15-к (кримінальні справи (до 01.01.2019)). URL: http:/ /www. reyestr.court.gov.ua/ Review/46588255.

Косаняк С. С., аспірант кафедри кримінального права та процесу Львівського торговельно-економічного університету 